\title{
Investors' Protection, Corruption and Legal Origin on the Equity Market Volatility: A Global Perspective
}

\author{
Usha Rajagopalan $^{1}$, Sheela Devi D. Sundarasen ${ }^{2} \&$ Nakiran Rajangam ${ }^{1}$ \\ ${ }^{1}$ Taylor's Business School, Taylor's University, Malaysia \\ ${ }^{2}$ Multimedia University, Cyberjaya, Malaysia \\ Correspondence: Sheela Devi D. Sundarasen, Multimedia University, Cyberjaya, Malaysia. E-mail: \\ sundarasen.sheela@gmail.com
}

Received: March 2, 2014 Accepted: March 25, 2014 Online Published: May 30, 2014

doi:10.5539/ass.v10n11p269

URL: http://dx.doi.org/10.5539/ass.v10n11p269

\begin{abstract}
This study explores the relationship between the roles played by institutional factors such as investors' protection, corruption and legal origin on the global equity market volatility using a panel data over a period of 5 years; 2008 - 2012. Ninety-one countries were selected based on data availability from the World Bank. Generalized moving methods (GMM) is employed to identify the short and long-run effects of the abovementioned relationship. The results indicate that investors' protection and legal origin play a significant role in the equity market volatility for all countries. It is conjectured that proper investors' protection and legal execution are important for a country to have a stable equity market because this mitigates uncertainty and increases investor confidence. Further analysis on sub-groups (Emerging Markets and Developed Markets) indicate that all three variables analysed in this study, i.e., investors protection, transparency levels and legal origin have an impact on the volatility of a stock market. High transparency level coupled with low corruption level creates more confidence amongst investors in the developed countries as opposed to the emerging markets and this reduces the volatility. Taken together, the results clearly signal to the market that investors are cautious on the extent of protection given by a country, its transparency levels and the legal content and enforcement.
\end{abstract}

Keywords: equity market, volatility, legal origin, investors' protection and transparency levels

\section{Introduction}

\subsection{Introduction to Problem}

In today's borderless economy, equity markets are constantly exposed to changes in domestic and foreign economic policies, regulations, political upheavals and natural calamity happening in any one corner of the globe. Largely, the performance of the equity market is at the will of the Bull/Bear cartel working overtime and the movement and spillover of funds from one zone to another. This causes volatility in the equity markets and the major concern for the investing groups is the inherent risk due to the volatility. Volatility in this context refers to the relative rate at which the stock index moves. Rapid movement of the stock index over short time periods is considered as high volatility, whilst price resilience denotes low volatility.

Such rapid movements in an equity market are an unappealing trait as it has undesirable insinuations for choices pertaining to valuable distribution of funds. Excessive or extreme volatility of any stock index may be detrimental to an economy for several reasons; it may impair or interrupt the performance of the financial system and could influence regulatory bodies to make major changes to regulations, in order to create a more resilient market. These major changes to the regulations are normally not well perceived by the investing communities. Investors may shift their funds and business investment spending to less risky assets or less risky countries (Zuliu, 1995) and this will subsequently affect the economic growth (Levine \& Zervos, 1998). Stock price volatility could also hinder economic performance through consumer spending (e.g., Campbell, 1996; Starr-McCluer, 1998; Ludvigson \& Steindel, 1999; Poterba, 2000) as a more predictive market assist investors in their short and medium term spending. Thus, it is imperative to identify the major attributes to the global equity market volatility, which is discussed in the following section.

\subsection{Relevant Literature}

Finance literature has documented quite extensively that equity market returns of both the developing and 
developed markets are susceptible to macroeconomic news, financial data and statements pertaining to regulatory changes in a country's policy (e.g., Boudoukh \& Richardson, 1993; Mandelker \& Tendon, 1985). Volatility in the equity market is also subject to money supply, inflation, reports pertaining to industrial outputs and current account, (Kearney \& Daly, 1998, Errunza \& Hogan, 1998, Beltratta \& Moranab 2006), interest rates (Chinzara, 2010, Diab \& Mohammed, 2012) and foreign trading volume (Liljeblom \& Stenius, 1997). The empirical literature provides contradictory conclusions with regard to the elaborate association between exchange rate and equity markets. Initial research by Jorion (1990) suggests that adjustments in exchange rate has no direct impact on the volatility of stock returns, whilst others (see e.g. Walid, Chaker, Masood \& Fry, 2011; Aggarwal, Inclan, \& Leal, 1999; Dumas \& Solnik, 1995; Roll, 1992; Ping Wang and Tomoe Moore, 2009) claim the presence of a strong association between changes in exchange rate and equity market instability. Investors' sentiments also play a significant role in the volatility of an equity market, (Alexander Kurov, 2010). Similarly, literature documents that the category of investors, i.e., retail, institutional and foreign investors have different level of impact on the volatility of equity markets (Bae, Stulz \& Tan, 2008; Choe, Kho, \& Stulz, 1999; Thaler 2005; Karolyi, 2002; Kamesaka, Nofsinger, \& Kawakita, 2003).

Another widely discussed issue on the equity market volatility is liberalization, as it is argued that augmented liberalization does pave way for rogue traders to cause instability in the equity market, thus causing rapid volatility. Contrary to that, research also documents that liberalization has reduced volatility as informed investors are more vigilant and cautious on the market movement (Holmes \& Wong, 2001). Studies have also noted that liberalization on the regulation of a country's equity market, especially in terms of foreign investors may have a positive or negative impact on the volatility but it is very country-specific; countries that practice superior accounting standards, better laws pertaining to investor protection and repatriation of funds, and low corruption have lower volatility (Barton \& Waymire,2004; Jayasuria, 2005). Similarly, an increase in financial integration reduces the volatility, (Esqueda, Assefa \& Mollick, 2012).

To further compliment the above literature, this study attempts to contribute in terms of the roles played by institutional factors such as legal origin, transparency levels and investors' protection on the global equity market volatility. Based on the discussion above, it is noted that minimal studies has been undertaken to analyse the impact of institutional factors (legal origin, investors protection and transparency level) on the global equity market. With respect to the country of legal origin, La Porta, Lopez-de-Silanes, Shleifer, Vishny (henceforth, LLSV), (2007) highlighted that there are two major laws: the Common law and the Civil Law (which includes French, German and Scandinavian law). Countries under the Common law regime emphasizes on the importance of protection of minority shareholders whereas French civil law countries are relatively relaxed in that respect. It is also noted that the implementation of regulations are more imminent in common law countries, irrespective of the level of economic prosperity of a country.

LLSV $(1997,1998)$ highlighted that protection given by a country's legal system on the minority shareholders from expropriation increases their involvement in the equity market, thus having a lower impact on the volatility as opposed to countries with weak legal system and concerted ownership. Another issue of contention is on the corruption level of a country, whereby common law countries generally experience lower corruption and thus a more effective market force comes into play. This ultimately reduces the volatility in the equity market. In contrast, in dictatorial regimes, execution of regulations and laws are less successful.

Legal origins also show a key role in a "country's laws on creditor rights, shareholder rights and private property rights as well as the stock market development", LLSV (1998). LLSV (2000) advanced to highlight on the impact of expropriation by insiders on the shareholders and creditors. It is stressed that protection for all stakeholders, via the legal standards is pivotal for the advancement of a capital market as expropriation is spiraling in many countries. Therefore, investor protection via legal system (both law and enforcement) is a set of mechanism through which outside investors protect themselves against expropriation by the insiders. Civil law is allied to larger state interference in financial market activities and lower protection on minority shareholders and creditors compared to common law.

This is further supported by LLSV (2007), whereby it is conjectured that countries that have structured regulations and policy pertaining to investor's protection are more stabile as investors' confidence level increases. A more stringent regulatory system mitigates the possibilities of insiders to undertake any unfavorable acts at the expense of the minority shareholders. Literature documents that Common law countries practice a higher level of protection on minority shareholders compared to Civil law countries. In conclusion, common law countries show evidence of a superior extent of investor protection and thus contributing to more mature and stabile capital markets. 
In addition to the importance of country of legal origin and investors' protection, corruption appears to be another main cause of uncertainty in the solidity of a financial system. Transparency International defines corruption as "the abuse of entrusted power for private gain". This description includes corruption at public and state level. Countries that place importance on transparency levels tend to be less corrupt, thus mitigates the level of ex-ante uncertainty and lowers the volatility in the equity market.

In conclusion, the extant literature demonstrates that the major factors affecting the volatility in an equity market are: economic policies, interest rates, iflation rates, investor's trade, exchange rate, stock market liberalisation, major political changes etc. Extant literature has very limited study on the roles played by institutional arrangements such as legal origins, investor's protection and transparency levels and its impact on the volatility of global equity markets. This study envisions to bridge those possible gaps. Country of legal origin will be analyzed from the perspective of common law and non-common countries, transparency levels will be proxied by corruption perception index whilst investors' protection will be further analyzed in terms of Extent of Disclosure Index (EDI), Extent of Director Liability Index (EDLI) and Ease of Shareholder Suits Index (ESSI). The following section illustrates the framework and hypotheses.

\subsection{Conceptual Framework and Hypotheses Development}

Based on the extant literature, the following framework is drawn:

\section{CONCEPTUAL FRAMEWORK}

\section{INVESTORS' PROTECTION}

Extent of Disclosure Index
Extent of Director Liability Index
Ease of Shareholder Suits Index
Strength of Investor's Protection Index

COUNTRY OF LEGAL ORIGIN

\section{Common Law}

Non-common law
TRANSPARENCY LEVEL
Proxied by Corruption

Perception Index

The hypotheses tested are as below:

$\mathrm{H}_{1 \mathrm{a}}$ : Extent of Disclosure Index has a positve impact on the volatility of an equity market.

$\mathrm{H}_{1 b}$ : Extent of Director Liability Index has a positve impact on the volatility of an equity market.

$\mathrm{H}_{1 \mathrm{c}}$ : Ease of Shareholder Suits Index has a positve impact on the volatility of an equity market.

$\mathrm{H}_{1 \mathrm{c}}$ : Strength of Investor's Protection Index has a positve impact on the volatility of an equity market.

$\mathrm{H}_{2}$ : Country of legal origin has a positve impact on the volatility of an equity market.

$\mathrm{H}_{3}$ : Transparency has a positve impact on the volatility of an equity market.

\section{Methodology}

This study uses a panel data over a period of 5 years; 2008 - 2012. At the initial stage, one hundred and eighty seven countries are selected based on data availability for Investor's Protection index by World Bank. Seventy-six countries were dropped due to unavailability of the closing equity index, whilst another 20 countries were dropped due to unavailability of lending interest rates (control variable). The final number of countries analyzed is ninety-one countries. Data for this study is obtained mainly from the World Bank, OSIRIS, DataStream, Bloomberg, CEIC, Passport, EMIS and database.

The study uses equity market volatility as the dependent variable and the independent variables are; Investors' Protection level, Country of Legal Origin, and Transparency levels of a country. Investors' protection is further analyzed based on the following perspectives; extant of disclosure index (EDI), extant of director's liability index (EDLI), shareholder's suit index (ESSI) and the strength of investor's protection index (ESSI) while corruption perception index (CI) is used as a proxy to the transparency levels. As for the country of legal origin, this study has considered two main legal origins; common law and non-common law. The control variables are 
the macroeconomic factors represented by consumer price index (CPI), foreign direct investment (FDI), lending interest rate (IR), real effective interest rate (REIR) and gross domestic product (GDP).

Volatility of the equity market is found by calculating the annualized standard deviation of daily change in price. As for the Investors' Protection Index, the following information is obtained from the World Bank Website; "Extent of disclosure refers to the disclosure and approval requirements; Extent of director liability refers to the ability to sue directors for damages; Ease of shareholder suits refer to the access by shareholders to documents plus other evidence for trial." All the above mentioned index ranges from $0-10$. The ranking on "the strength of investor protection index" is the simple average on the "extent of disclosure, extent of director liability and ease of shareholder suits indices'. A ranking of 10 mean that the country has a high level of investor protection.

The transparency levels are proxied by Corruption Perceptions Index (CI) from Transparency International (TI). The $\mathrm{CI}$ is a collective index/reference that merges divergent sources of details on corruption; both administrative and political characteristics related to corruption. To determine the index, surveys are conducted on a wide spectrum of issues including, bribery of public officials, kickbacks expropriation public procurement, misappropriation of public finances, and issues related to effort by government curbing corruption.

GMM is employed in this study to look into the short and long-run effects. All the data are expressed in terms of natural $\log$ in order to include proliferate effects of time series and eliminate heteroscedasticity. Since all the variables are in natural logarithm, the first differences show the elasticity of the variables, in other words the rate of growth for the variables or the percentage change.

The empirical model employed in this study is as follows:

Where;

$$
v_{i t}=\alpha+\sum_{j=1}^{m} \delta_{j} y_{i, t-j}+\sum_{i=0}^{n} \beta_{i} x_{i, t-l}+\sum_{k=0}^{\gamma} \gamma_{k z_{i, t-k}}+u_{i t},
$$

$t=1,2, \ldots, T$ is the time,

$i=1,2, \ldots, N$ is the cross sectional frame while the highest lags are denoted as $m, n$, and $r$,

$y_{i t}=$ volatility of equity markets in country $i$,

$y_{i, t-j}=$ volatility of equity markets in country $i$ of previous periods with lags of $j$ periods,

$x_{i, t-l}$ Represents a set of investors' protection variables lags of $l$ periods,

$z_{i, t-k}$ Represents transparency level lags of $k$ period,

aRepresents the constant term or the intercept,

$\delta_{\mathrm{j}}$ Represents the coefficients for the volatility of equity market in country $i$ of previous periods with lags of $j$ periods,

$\beta_{l}$ Represents the coefficients for a set of investors' protection variables with lags of $l$ periods,

$\gamma_{k}$ Represents the coefficients for the transparency levels with lags of $k$ period,

$u_{i t}$ Represents the error term.

Initially this study was to estimate the above equation using the Ordinary Least Squares or Pool Mean Group. But, the OLS estimates tend to suffer from biasness due to the unobserved heterogeneity from the cross sectional data. To overcome this problem the system GMM is employed. The system GMM is a dynamic model popularized by Arellano and Bover $(1991,1995)$ and also Blundell and Bond (1998). The Difference GMM is done by transforming all regressors by differencing and then employs the GMM. The system GMM is a combination of the two equations which are the original GMM equation with the transformed one. This system GMM is considered better than Difference GMM because problems regarding finite sample bias caused by weak instruments in the Difference GMM are addressed in Dynamic Panel System GMM. The GMM estimator that combines the moment conditions for the differenced model with those for the levels model is call the SYSTEM estimator (Blundell and Bond, 1998) and has been proven to execute better. Arellano and Bond (1991) have designed firstly the one step estimator, then later the two step estimator which renders to be the optimal estimator.

The GMM panel estimator based on first differencing of the above equation is as follows:

$$
\begin{gathered}
y_{i t}-y_{i t-1}=\rho+\sum_{j=1}^{m} \delta_{j}\left(y_{i, t-j}-y_{i, t-j-1}\right)+\sum_{i=0}^{n} \beta_{i}\left(x_{i, t-l}-x_{i, t-l-1}\right)+\sum_{k=0}^{\gamma} \gamma_{k}\left(z_{i, t-k}-z_{i, t-k-1)}+\left(u_{i t}-\right.\right. \\
\left.u_{i t-1}\right)
\end{gathered}
$$

It is assumed that the error term, $u_{i t}$, is one way error component model. 


$$
u_{i t}=\gamma_{i}+v_{i t}
$$

Where $\gamma_{i}$ the unobserved country is specific effect and $v_{i t}$ is the idiosyncratic error term for each observation. It is assumed that the distributions for each specific effect in the error component model are $\gamma_{i} \sim \operatorname{iid}\left(0, \sigma_{\gamma}^{2}\right)$, and $v_{i t} \sim \operatorname{iid}\left(0, \sigma_{v}^{2}\right)$

In the above equation, the term on the left represents the equity market volatility at time t. They $x_{i, t-l}$ are assumed to be weakly exogenous to the term on the left which is the $y_{i t-} y_{i t-1}$. There is a possible endogeneity between the regressors $z_{i, t-k}$ and the difference in the error term. In order to correct this, the GMM first difference estimator uses the following moment conditions

$$
\begin{aligned}
& E\left[y_{i, t-j}\left(u_{i t}-u_{i t-1}\right)\right]=0 \text { For } j \geq 2 ; t=3,4 \ldots 7 . \\
& E\left[z_{i, t-k}\left(u_{i t}-u_{i t-1}\right)\right]=0 \text { For } k \geq 2 ; t=3,4 \ldots 7 .
\end{aligned}
$$

Moment condition as above will correct the "potential endogeneity, unobserved country heterogeneity, omitted variable bias and measurement errors", (Tsai et al., 2010)

The dynamic panels above are described by two basis; autocorrelation since there exist a lagged dependent variable among the regressors and individual effects illustrating the heterogeneity among the individuals. Since $u_{i t}$ is a function of $\gamma_{i}$, and $y_{i t}$ is a function of $\gamma_{i}$, thus it is apparent that $y_{i, t-j}$ is also a function of $\gamma_{i}$. Consequently the right hand regressor $y_{i, t-j}$ in the first equation is interrelated to the error term. This correlation causes the Ordinary Least Squares (OLS) estimator bias and affects the consistency.

\section{Analysis and Discussion}

3.1 Impact of Investors' Protection, Corruption Level and Country of Legal Origin on the Equity Market Volatility in the Emerging and Developed Markets

Table 1. Regression results on the impact of investors' protection, corruption level and country of legal origin on the equity market volatility for all markets, emerging markets and the developed markets

\begin{tabular}{lcccccc}
\hline & \multicolumn{2}{c}{ All Markets } & \multicolumn{2}{c}{ Emerging } & Markets & \multicolumn{2}{c}{ Developed Markets } \\
\hline & Coefficient & Std. Error & Coefficient & Std. Error & Coefficient & Std. Error \\
\hline Investors' Protection & & & & & & \\
Log EDI & $-3.045^{* * *}$ & $(-3.939)$ & 1.897 & $(1.063)$ & $-25.866^{* * *}$ & $(-11.956)$ \\
Log ESSI & $-3.629^{* * *}$ & $(-4.261)$ & 2.711 & $(1.017)$ & $-27.154^{* * *}$ & $(-14.108)$ \\
Log EDLI & $-15.038^{* * *}$ & $(-9.049)$ & 1.31 & $(0.591)$ & $-16.451^{* * *}$ & $(-8.055)$ \\
Log SIPI & $-10.069^{* * *}$ & $(-17.028)$ & $-6.779 * * *$ & $(3.149)$ & $-76.838^{* * *}$ & $(-35.974)$ \\
Corruption Level & & & & & & \\
Log CI & -0.682 & $(-1.629)$ & 1.029 & $(0.440)$ & $-1.644^{* *}$ & $(-1.955)$ \\
Country of Legal Origin & & & & & & \\
Legal Origin & $-1.118^{*}$ & $(-1.728)$ & 1.369 & $(0.491)$ & $4.104^{*}$ & $(1.680)$ \\
Control Variables & & & & & & \\
Log REER & $-2.697^{* *}$ & $(-2.16)$ & -2.616 & $(1.415)$ & $-6.689^{* * *}$ & $(-1.797)$ \\
Log LenRate & -0.502 & $(-0.292)$ & 0.339 & $(0.285)$ & $1.236^{* * * *}$ & $(0.288)$ \\
Log CPI & -1.422 & $(-1.317)$ & -0.541 & $(0.327)$ & $-1.327^{* * *}$ & $(-3.644)$ \\
Log FDI & -0.101 & $(-0.144)$ & -0.776 & $(0.126)$ & $-0.335^{* * *}$ & $(-0.112)$ \\
Log GDP & -1.725 & $(-0.995)$ & 0.606 & $(0.268)$ & 0.464 & $(0.328)$ \\
\hline
\end{tabular}

$* * *$ significant at $1 \%$ level; figures in parenthesis are the $\mathrm{p}$-value

EDI - Extent of Disclosure Index; EDLI- Extent of Directors Liability Index; ESSI- Extent of Shareholders Suit Index SIPI - Strength of Investors Protection Index; CI- Corruption Index; Legal Origin - Country of Legal origin; REER - Real Effective Ex- change Rate; Len Rate - Lending Rate; CPI - Consumer Price Index; FDI Foreign Direct Investment; GDP - Gross Domestic Product. 
Table 1 shows the results of the relationship between the investors' protection, transparency levels of a country and the legal origin on the equity market volatility. The control variables are not significant in the main model (encompassing all countries in the study) except for Real Effective Exchange Rate but in the developed countries, all the control variables (except GDP) show significant relationship against the equity market volatility.

The results of the independent variables, generally indicate that investors' protection play an important role in the volatility of a stock market. Nevertheless, a further breakdown of countries into Emerging and Developed Markets indicate that investors' protection play a pivotal role in the volatility of the Developed Markets but not in the Emerging Markets. Columns 2 and 3 shows the results for all the countries tested in this sample, whilst columns 4 and 5 shows for the Emerging Markets. Columns 6 and 7 displays results for the Developed Markets. All sub-components of investors' protection, Extent of Disclosure Index, Extent of Directors Liability Index, Extent of Shareholders Suite Index and Strength of Investors Protection Index have a negatively significant impact on the volatility of an equity markets, meaning the higher the protection level given by a country to the investors, the lower the volatility of the equity markets. As for the Emerging Markets, only Strength of Investors Protection Index have a significantly negative impact on the volatility of equity market. This is in line with the findings of LLSV $(1997,1998)$, who argued that regulations that emphasise on the importance of protecting outside stakeholders will see a more stable market as it increases investors confidence, ultimately encouraging more participation. Investors' protection play a very pivotal role as many countries experience expropriation by insiders. Thus, the results conjecture that countries that practices high level of investors' protection have a more stable equity market as uncertainty and fear is mitigated.

The next section on Table 1 indicates that transparency level of a country, which is proxied by the corruption perception index (from Transparency International). It does not have any significance on the volatility of the equity market in all markets (in general) and in the Emerging Market. Nevertheless, a significantly negative relationship is denoted in the Developed Markets. This indicates that countries with low corruption level (denoted by high transparency index) in the developed markets has a lower level of the equity market volatility. High transparency level reflects lower level of corruption and this mitigates uncertainty in the equity market, low government intervention, and a higher level of enforcement in the developed countries. This increases investor confidence and results in a lower level of equity market volatility.

As for the legal origin of a country, the results in Table 1 indicates that, in general, the common law countries have a lower volatility in the equity market compared to the non-common law countries but in the developed markets, the results are rather contrasting, whereby a negative relationship is denoted; Common law countries experience a higher volatility in the equity market compared to the non-common law counterparts. In general, civil law countries are associated with a higher level of state interference in economic activities and fragile protection of outside investors compared to common law countries. Common law countries have an elevated level of protection and a more matured financial market.

\section{Conclusion}

In conclusion, the overall view based on all the countries is that, investors' protection and legal origin of a country play a significant role in the equity market volatility of a country. It is conjectured that proper investors' protection and legal execution are important for a country to have a stable equity market because this mitigates uncertainty and increases investor confidence. Similarly, further analysis on sub-groups (Emerging Markets and Developed Markets) indicate that investors protection, transparency levels and legal origin are important elements affecting the volatility of a stock market. High transparency level coupled with low corruption level creates more confidence amongst investors in the developed countries as opposed to the emerging markets and this is this reduces the volatility. Taken together, the results clearly signal to the market that investors are cautious on the extent of protection given by a country, its transparency levels and the legal content and enforcement practiced by countries.

\section{References}

Aggarwal, R., Inclan, C., \& Leal, R. (1999). Volatility in emerging stock markets. Journal of Financial and Quantitative Analysis, 34(1). http://dx.doi.org/10.2307/2676245

Al-Raimony, A. D., \& El-Nader, H. M. (2012). The Sources of Stock Market Volatility in Jordan. International Journal of Economics and Finance, 4(11). http://dx.doi.org/10.5539/ijef.v4n11p108

Al-Sharkas, A. (2004). The Dynamic Relationship between Macroeconomic Factors and the Jordanian stock market. International Journal of Applied Econometrics and Quantitative Studies, 1(1), 97-114. 
Bae, K. H., Stulz, R. M., \& Tan, H. (2008). Do local analysts know more? A cross-country study of the performance of local analysts and foreign analysts. Journal of Financial Economics, 88(3), 581-606. http://dx.doi.org/10.1016/j.jfineco.2007.02.004

Barton, J., \& Waymire, G. (2004). Investor protection under unregulated financial reporting. Journal of Accounting and Economics, 38, 65-116. http://dx.doi.org/10.1016/j.jacceco.2004.06.001

Billio, M., \& Pelizzon, L. (2003). Journal of Multinational Financial Management, 13, 323-340. http://dx.doi.org/10.1016/S1042-444X(03)00014-8

Boudoukh, J., \& Richardson, M. (1993). Stock returns and inflation: A long-horizon perspective. The American economic review, 83(5), 1346-1355.

Cai, Y. J., Chou, R. Y., \& Li, D. (2009). Journal of Banking \& Finance, 33, 2026-2035. http://dx.doi.org/10.1016/j.jbankfin.2009.05.013

Campbell, J. Y. (1996). Consumption and the stock market: Interpreting international experience (No. w5610). National Bureau of Economic Research.

Chinzara, Z. (2010). Macroeconomic uncertainty and emerging market stock market volatility: The case for South Africa. Working paper 187, August 2010, pp. 1-19.

Choe, H., Kho, B. C., \& Stulz, R. M. (1999). Do foreign investors destabilize stock markets? The Korean experience in 1997. Journal of Financial Economics, 54(2), 227-264. http://dx.doi.org/10.1016/S0304-405X(99)00037-9

Dumas, B., \& Solnik, B. (1995). The world price of foreign exchange risk. Journal of Finance, 50, 445-477. http://dx.doi.org/10.1111/j.1540-6261.1995.tb04791.x

Errunza, V., \& Hogan, K. (1998). Macroeconomic determinants of European stock market volatility. European Financial Management, 4, 361-377. http://dx.doi.org/10.1111/1468-036X.00071

Esqueda, O. A., Assefa, T. A., \& Mollick, A. V. (2012). Financial globalization and stock market risk. Journal of International Financial Markets, Institutions and Money, 22(1), 87-102. http://dx.doi.org/10.1016/j.intfin.2011.07.006

Ezaat, H. (2011). The Application of GARCH and EGARCH in Modeling the Volatility of Daily Stock Returns during Massive Shocks: The Empirical Case of Egypt. International Research Journal of Finance and Economics Issue, 96.

Holmes, P., \& Wong, M. W. (2001). Foreign investment, regulation and price volatility in South-east Asian stock markets. Emerging Markets Review, 2(4), 371-386. http://dx.doi.org/10.1016/S1566-0141(01)00025-5

Iltuzer, Z., \& Tas, O. (2012). The Analysis of Bidirectional Causality between Stock Market Volatility and Macroeconomic Volatility. International Journal of Business and Social Science, 3(12).

Jayasuriya, S. (2005). Stock market liberalization and volatility in the presence of favorable market characteristics and institutions. Emerging Markets Review, 6(2), 170-191. http://dx.doi.org/10.1016/j.ememar.2005.03.001

Jirasakuldech, B., Dudney, D. M., Zorn, T. S., \& Geppert, J. M. (2011). Review of Quantitative Finance and Accounting, 37(2), 181-205. http://dx.doi.org/10.1007/s11156-010-0200-5

Jorion, P. (1990). The exchange rate exposure of the U.S. multinationals. Journal of Business, 63, 331-345. http://dx.doi.org/10.1086/296510

Kamesaka, A., Nofsinger, J. R., \& Kawakita, H. (2003). Investment patterns and performance of investor groups in Japan. Pacific-Basin Finance Journal, 11(1), 1-22. http://dx.doi.org/10.1016/S0927-538X(02)00095-1

Karolyi, G. A. (2002). Did the Asian financial crisis scare foreign investors out of Japan? Pacific-Basin Finance Journal, 10(4), 411-442. http://dx.doi.org/10.1016/S0927-538X(02)00067-7

Kearney, C., \& Daly, K. (1998). The causes of stock market volatility in Australia. Applied Financial Economics, 8, 597-605. http://dx.doi.org/10.1080/096031098332637

La Porta, R., Lopez-de-Silanes, F., Shleifer, A., \& Vishny, R. (1997). Legal determinants of external finance. Journal of Finance, 52, 1131-1150. http://dx.doi.org/10.1111/j.1540-6261.1997.tb02727.x

La Porta, R., Lopez-de-Silanes, F., Shleifer, A., \& Vishny, R. (1998). Law and finance. Journal of Political Economy, 106, 1113-1155. http://dx.doi.org/10.1086/250042 
La Porta, R., Lopez-de-Silanes, F., Shleifer, A., \& Vishny, R. (2000). Agency problems and dividend policies around the world. Journal of Finance, 55, 1-33. http://dx.doi.org/10.1111/0022-1082.00199

Levine, R., \& Zervos, S. (1998). Capital control liberalization and stock market development. World Development, 26, 1169-1183. http://dx.doi.org/10.1016/S0305-750X(98)00046-1

Liljeblom E., \& Stenius, M. (1997). Macroeconomic volatility and stock market volatility: empirical evidence on Finnish data. Applied Financial Economics, Taylor and Francis Journals, 7(4), 419-426. http://dx.doi.org/10.1080/096031097333538

Ludvigson, S. C., \& Steindel, C. (1998). How important is the stock market effect on consumption? (No. 9821). New York: Federal Reserve Bank of New York.

Mandelker, G., \& Tandon, K. (1985). Common stock returns, real activity, money and inflation: Some international evidence. Journal of International Money and Finance, 4, 267-286. http://dx.doi.org/10.1016/0261-5606(85)90048-8

Morelli, D. (2002). The relation between conditional stock market volatility and conditional macroeconomic volatility Empirical evidence based on UK data. International Review of Financial Analysis, 11, 101-110. http://dx.doi.org/10.1016/S1057-5219(01)00066-7

Mun, M., \& Brooks, R. (2012). The roles of news and volatility in stock market correlations during the global financial crisis. Emerging Markets Review, 13, 1-7. http://dx.doi.org/10.1016/j.ememar.2011.09.001

Poterba, J. M. (2000). Stock market wealth and consumption. The Journal of Economic Perspectives, 14(2), 99-118. http://dx.doi.org/10.1257/jep.14.2.99

Roll, R. (1992). Industrial structure and the comparative behavior of international stock market indices. The Journal of Finance, 47(1), 3-41. http://dx.doi.org/10.1111/j.1540-6261.1992.tb03977.x

Rousan, R., \& Al-Khouri, R. (2005). Modeling Market Volatility in Emerging Markets in the Case of daily Data in Amman Stock Exchange 1992-2004. International Journal of Applied Econometrics and Quantitative Studies, 2(4), 99-118.

Starr-McCluer, M. (1998). Stock market wealth and consumer spending. Division of Research and Statistics, Division of Monetary Affairs, Federal Reserve Board.

Thaler, R. H. (Ed.). (2005). Advances in behavioral finance (Vol. 2). Princeton University Press.

Walid, C., Chaker, A., Masood, O., \& Fry, J. (2011). Stock market volatility and exchange rates in emerging countries: A Markov-state switching approach. Emerging Markets Review, 12(3), 272-292. http://dx.doi.org/10.1016/j.ememar.2011.04.003

Wang, P., \& Moore, T. (2009). Sudden changes in volatility: The case of five central European stock markets. Journal of international financial markets, institutions and money, 19(1), 33-46. http://dx.doi.org/10.1016/j.intfin.2007.08.006

\section{Copyrights}

Copyright for this article is retained by the author(s), with first publication rights granted to the journal.

This is an open-access article distributed under the terms and conditions of the Creative Commons Attribution license (http://creativecommons.org/licenses/by/3.0/). 